\title{
ARTICLES \\ From Ritual Object To Art Form: The Ukrainian Easter Egg Pysanka In Its Canadian Context (1)
}

\author{
Mariya Lesiv \\ University of Alberta
}

"I would like to have a goose that would lay such eggs," said Prince Philip, amazed by the spectacular pysanky made of goose eggs, which the royal family received as a gift from Mrs. Sembaliuk in Vegreville, Alberta, during their visit in 1978.(2) Although I came to Canada from Ukraine, where the tradition of pysanka writing has been developing (predominantly in rural areas) since at least a century ago, and thus I was quite well acquainted with it, I was also surprised by the specifically Ukrainian Canadian pysanka.(3) The physical shapes of Ukrainian Easter eggs and their functions in a Canadian environment were both familiar and unexpectedly unfamiliar to me. These objects manifested how dynamic a tradition can become in a different socio-cultural context, so I began further research in order to understand these dynamics better.

Part of this study is based on the ethnographic research method fieldwork - including interviews and participant observation.(4) Empirical data was collected from Ukrainian Canadian women's periodicals that often discussed pysanky on their pages.(5) I also consulted published reports on early large Ukrainian Canadian women's organizations that actively incorporated the pysanka into their activities as well as various popular publications (post cards, brochures and books) devoted specifically to Ukrainian Easter eggs.(6)

Transferred from the land of its origin to the New Country, the pysanka became a potent and creative mode of expression among Ukrainian Canadians. My research demonstrates that Ukrainian Easter eggs were deeply incorporated into the historical, political, social, cultural and economic context of Ukrainian Canadian communities. Their evolutionary process in the New Country was indeed complex, yielding different sub-traditions. In this article, I will focus on two distinct patterns of pysanka development in Canada. I call them the "Old Country" and the "National/Ethnic" paradigms.(7) While discussing each paradigm separately, I will first concentrate predominantly on empirical data, and then provide a more theoretical interpretation of the factual material. At the end, I will focus specifically on the notion of aesthetics as related to the pysanky of both trends. 
Both emic and etic perspectives will be presented in this work. Anthropologist James Lett defines the terms usefully for the present study:

...Emic refers to the native's viewpoint; etic refers to the scientist's viewpoint. Emic constructs are descriptions and analyses conducted in terms of the conceptual schemes and categories considered meaningful by the participants in the event or situation being described and analyzed. Etic constructs are descriptions and analyses conducted in terms of the conceptual schemes and categories considered meaningful by the community of scientific observers. [Lett 62]

In accordance with these definitions, I consider the emic perspective as the one that reflects the view of people writing pysanky while the etic perspective is my own interpretation and analysis.

To illustrate the difference between the Old Country and the National/Ethnic paradigms, I will touch upon the same key concepts related to the pysanky of both patterns: transmission (the process of acquiring knowledge, and passing it on to others), form (the physical shape of the pysanka, which in most cases depends on the kind of egg used) and design (the artistic arrangement on the form), production (the technical methods of writing/making the pysanka), function (refers to various activities for which pysanky are used), and meaning (explains why the activities are undertaken and what they signify for a person or community).

This approach is inspired by early Ukrainian ethnographers and their studies of the pysanka in Ukraine. M. Sumtsov [1891], V. Shcherbakivs'kyi [1925], S. Kul'zhynskii [1899], M. Korduba [1899], V. Shukhevych [1899], and I. Hurhula [1929] approached their discussions of pysanky from the different ethnographic regions in Ukraine using either all or some of the key concepts listed above.(8) Their ethnographic works on pysanky in Ukraine in the late $19^{\text {th }}$ - early $20^{\text {th }}$ century serve as a significant source for the present study due to the rich empirical data they presented. Together, they provide a broad picture of this phenomenon as it existed in Ukraine before it was brought to Canada, forming a basis for tracing continuity and change in the New Country. Moreover, the works of such scholars as Shcherbakivs'kyi, Sumtsov and Kul'zhyns'kyi deserve separate emphasis since they had a special influence on the development of the Ukrainian Canadian National/Ethnic Easter eggs, as discussed below. The analytical approaches of these scholars are greatly influenced by the ideas of the European mythological school of folkloristics and specifically those of solar mythologists of the $19^{\text {th }}$ century, who were interested in the search 
for the origins of folklore materials, and who found these origins in the movements of celestial bodies.(9) Researching the pysanka, Shcherbakivs'kyi, Sumtsov and Kul'zhyns'kyi emphasize its pre-Christian origins, defining it as an ancient pagan symbol of the rebirth of the sun and nature. Moreover, they focus on particular pysanka motifs from all over Ukraine and neighboring territories, trying to trace their origins and advancing interpretations of their archaic meanings.

Only a few scholarly works devoted to Ukrainian pysanky were published in Canada. S. Kylymnyk [1969], similarly to his predecessors Sumtsov, Kul'zhyns'kii and Shcherbakivs'kyi, concentrates on the symbolic meaning of the pysanka presented in its ornamental motifs and functions in the context of old rituals. R. Klymasz's article [1969] deals specifically with the Ukrainian Canadian pysanka and its stages of development in a new setting: its retention by Ukrainian pioneers and its transformation into a symbol of Ukrainian ethnicity over time. M. O. Jones' article [1991] includes a brief interpretation of UkrainianCanadian pysanky in terms of their purposes, forms and designs in the context of constructing Ukrainian-Canadian identity.

\section{The Old Country Paradigm}

At the turn of the $19^{\text {th }}$ century, under the rule of the AustroHungarian Empire, Ukrainian peasants in the areas of Galicia and Bukovyna in Ukraine lived with "no special privileges and an enormous problem: the rapidly diminishing supply of their most precious possession - land" [Martynovych 1991: 4-5]. Forced by historical, social and economic conditions, they started coming to the Canadian prairies in the late $19^{\text {th }}$ century, looking for a way to improve their existence from what it was in the Old Country.(10) These Ukrainian pioneers brought knowledge of the pysanka, as a component of their Easter celebration, to the New country.

\section{Transmission}

The Old Country pysanka represents an unself-conscious continuation of the tradition of Ukrainian pioneers and their descendents. Writing pysanky was mostly a female activity.

This skill was taught orally, visually, and informally in the intimate social context (within a family or community) connected with the celebration of Easter: the novices listened, watched and copied. 


\section{Form and design}

Much as in Ukraine, Old Country pysanky were made most often with chicken eggs - the eggs most readily available on a farm. Their designs often represented specificities of the ethnographic region in Ukraine from which a family emigrated. This situation was also very similar to that in the villages of the Old Country. Although ethnographers who conducted research on pysanky in many areas of Ukraine were familiar with a variety of motifs represented by different regions, most participants in the tradition knew only the designs of their own village or vicinity, since peasants did not typically travel often. Due to the even greater geographical isolation of early prairie communities, the specific traditions remained very localized.

For example, in the area of Norquay, Saskatchewan, in the 1910s1930s, Joanna Janis's mother made pysanky as she remembered them from the village of Bortykivtsi in the Ternopil' region. The motifs of her pysanky were mostly geometric designs: "Chetver" [Thursday], "Piatnytsia" [Friday], "Velykden'" [Easter], "Pasochka" [Small Easter Bread] "Kuriacha lapka" [Chicken Foot] "Sorok klyntsiv" [forty triangles] (figures 1 and 2). They were written in two colors: white elements were situated on a black background. According to I. Hurhula, such motifs in terms of design and color palette were typical for the ethnographic territory of Podillia, where Bortykivtsi is located [Hurhula $133 ; 139]$.

Looking at Old Country pysanky from the point of view of an "art critic," one can easily see that one egg includes a relatively small number of motifs, each quite large. Applied with the help of a homemade stylus, the lines are fairly thick. The quality of the lines reflects the challenges of drawing on the curved surface of the eggshell.

\section{Production}

The pysanky were written with beeswax, a stylus, and dyes using the wax-resist technique.(11) The information gained from participants in this study corroborated Klymasz's findings that the first settlers used easily accessible and homemade materials to make pysanky [Klymasz 1969: 3]. The production process was fairly simple. Styluses were made out of wooden sticks and metal cans or tabs from the backs of calendars. Some respondents remembered their mothers and/or grandmothers making natural dyes, using onion skins for yellow and orange, beetroots for red, short buttercups for yellowish green and some other plants that were boiled, producing different colours. One of the marked innovations 


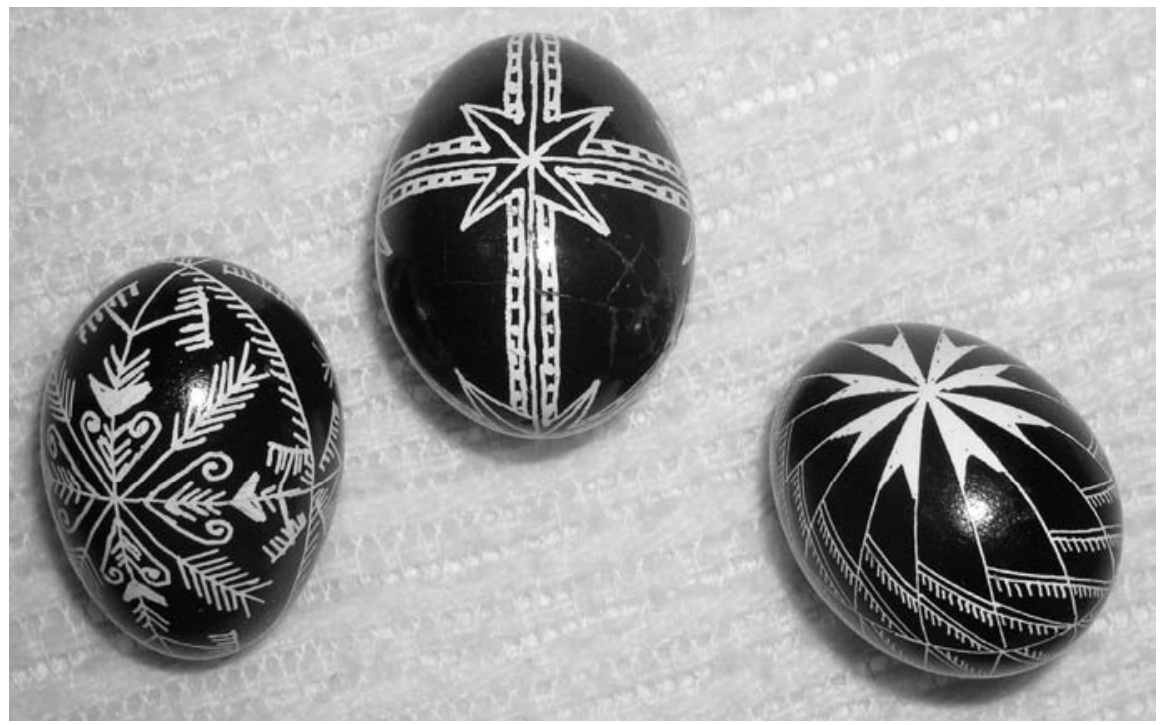

Figure 1. Old Country pysanky reproduced by J. Janis as remembered from her mother, writing in the 1920-1930s (Janis' private collection). Unless otherwise indicated, photographs from private collections were taken by M. Lesiv.
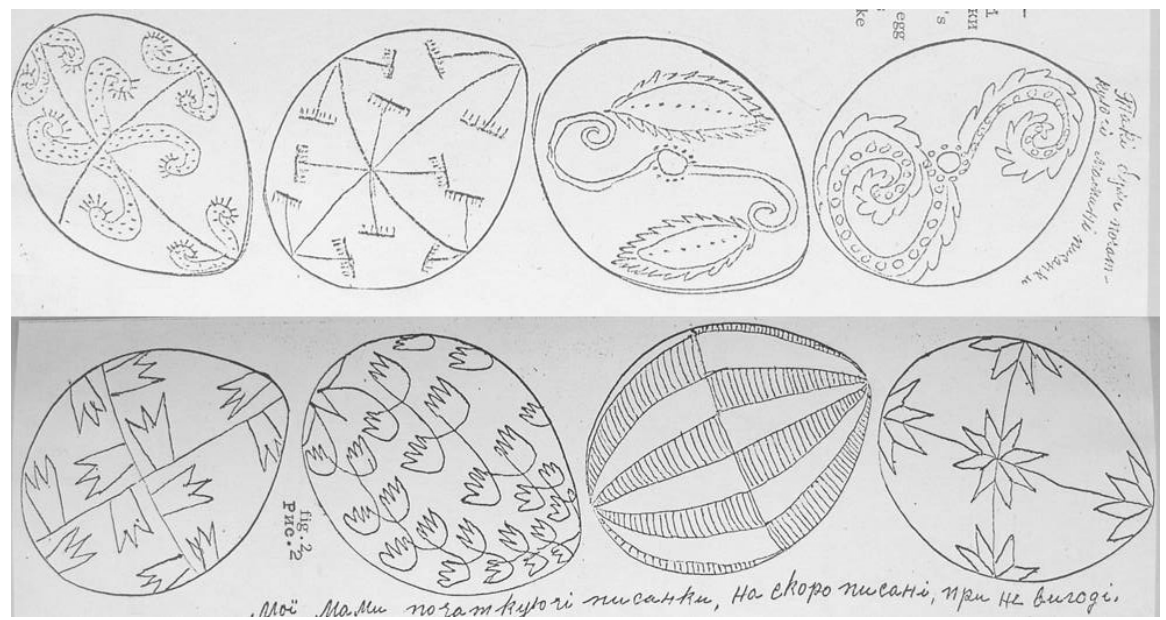

Figure 2. Pysanky of the Old Country paradigm. S. Porayko-Kyforuk's mother's initial pysanka designs from the early 1900s, sketched by PoraykoKyforuk [1969: 21]. 
introduced into pysanka writing in the first decades of the $20^{\text {th }}$ century was the use of commercially produced crepe paper in different colors. To make dyes, the crepe paper was soaked in very hot water until the water absorbed the color. With crepe paper, the palette of colors changed in terms of variety and saturation. A larger number of colors in much more intense shades became available.

Although, like those in the Old Country, early Ukrainian Canadian pysanky were most often made with raw eggs, it was not uncommon to write them on boiled eggs, and the latter were eaten on Easter.

\section{Function and Meaning}

On the emic level, the Old Country pysanka was foremost a ritual object, as in the Old Country. As in Ukrainian villages, the pysanka was connected predominantly with the Easter celebration and, in some cases, beliefs in its magical power remained. Joanna Janis showed the continuity of the Old Country religious and spiritual worldview within her family. On the farm, they decorated Easter eggs on Holy Thursday, as they used to do in the Old Country. Janis shared a prayer, taught by her mother, to be said each year before starting to write:

\footnotetext{
...We asked God to bless not only our work but the work that we did would be a blessing to us throughout the whole year and would bring good luck, and prosperity and health...At that time... it was sort of ingrained in us that if you didn't do it, you might have a very bad year... At the time, when I was doing it with my mother, I sincerely believed that...I should learn to do it because it would bring me good things in life.
}

Esther Mosychuk, describing the area of Two Hills, Alberta, in the 1930s, remembers a magical ritual connected with pysanky that her mother used to perform. Easter Sunday morning, they would put a dime and a krashanka (or pysanka) into a container of water and then wash their faces with the water.(12) According to earlier ethnographers' findings, this ritual was known in some areas of Ukraine, and was connected with the belief in the pysanka and/or krashanka as a talisman of beauty, strength and health: a face washed with this water will be beautiful and healthy [Korduba 180; Sumtsov 203].

In families where the old magical meaning behind certain rituals was lost, pysanka writing was still sometimes practiced as part of a traditional lifestyle. In these cases, the focus shifted to a social meaning, which could also be very important. The pysanka was tightly incorporated into social interaction within the family and community. For example, such widespread rituals as blessing pysanky in church and 
then exchanging them as gifts after the Easter service were remembered by most participants in this study as a very important part of their Easter celebration on Canadian farms. Undoubtedly it contributed to building a sense of community among the new settlers. In addition, pysanky were the objects of aesthetic appreciation in the context of spring and Easter celebrations. In general, according to the majority of the participants in this study, Old Country pysanky were not preserved for a long time.

\section{The Old Country Pysanka: Etic Interpretations}

The Old Country pysanky clearly correspond to the category of "pure" folk art, as defined in scholarship. Henry Glassie, in his definition, considers folk art to be "more collective than personal" ("more social than individualistic") and "more sacred than secular" [Glassie 1986: 271, 273]. Glassie underlines the aptitude of folk art to "center through abstraction upon the spiritual universe," "carry[ing] the social message" and "hold[ing] to the tradition" [Glassie 1986: 271]. In addition, this author emphasizes folk creativity as a result of "amateur inspiration" rather than "professional education" [Glassie 1986: 272]. Robert Klymasz enlarges the list of characteristic features of folk art by identifying such factors as unconscious retention of the tradition and its informal oral transmission, while talking about specifically Ukrainian Canadian folk creativity in pioneer times [Klymasz 1972: 7]. The Old Country pysanka clearly fits each of these characteristics: it tends to be collective, sacred, amateur, unconsciously retained, and transmitted orally and informally in the context of custom.

Although the creator considers any work she does her individual creation, from the etic perspective the Old Country pysanka remains a collective rather than individual form of expression. The origins of particular designs and the functions of the pysanka can be neither precisely determined nor attributed to any particular individual. Easter egg activities practiced in the early 20th century were the result of collective experiences brought from the Old Country and passed on to the subsequent generations in Canada, unconsciously "holding to the tradition." In this respect, the Old Country pysanka culture was inherited informally: the descendants of Ukrainian pioneers received their knowledge of it directly from older family/community members, transmitting it to younger generations within the same family (or community) in the context of their customary lifestyle.

As mentioned above, pysanky of the Old Country paradigm retained certain elements of traditional magical beliefs reflecting the peasants' old 
worldview, "represent[ing] the invisible by means of the visible" [Eliade 55]. Mircea Eliade considers such representation one of the characteristic features of sacred art, which "translate[s] religious experience and metaphysical conception of the world and of human existence into a concrete, representational form" [Eliade 55]. Within the pysanka tradition, such "religious experience" and "metaphysical conceptions" were accumulated in the form of an egg covered with certain designs, bearing what Glassie calls "the social message" and communicating "abstraction upon the spiritual universe."

\section{Pysanky of the National/Ethnic Paradigm}

In contrast to the Old Country pattern, the National/Ethnic paradigm (with emphasis on its "National" pole) is related to nationalist politics and conscious building of Ukrainian national/ethnic identity in Canada by a different socio-economic group. A nationalist outlook began actively developing among the Ukrainian intelligentsia in the second part of the $19^{\text {th }}$ century. Although it started to reach peasant rural communities at the same time, its expansion within the latter was not very rapid.(13) As a result, many peasants arriving in Canada with the first wave of immigration were not nationally conscious. Political consciousness started rising in western Canada after 1905 with the help of some representatives of the Ukrainian intelligentsia [Martynovych 1991: 244-247].(14) This outlook was reinforced in the interwar period by the "second wave of immigration," which included many representatives of the intelligentsia escaping from political unrest in Europe.(15) In Canada, these immigrants, joined by some descendents of the earlier Ukrainian settlers, put a concerted effort into building their distinctive national/ethnic identity. Many Ukrainian institutions were established for this purpose [Yuzyk 80-112; Martynovych 1991: 265305]. The nationalist outlook in Canada was greatly enhanced by Ukrainian political refugees, known as the "third wave of immigration," who arrived in Canada after World War II. Soviet totalitarian oppression in Ukraine gave an impulse for intensive cultural activity in Canada under appeals such as, "Let's always remember what our native land expects from us" [Zaiatseva 18].

\section{Transmission}

Starting with the first Ukrainian Canadian women's organizations in the late 1920s,(16) knowledge about pysanky began to be transmitted formally. It was passed on through numerous popular published sources 
(post cards, brochures and books) as well as through various structured activities such as pysanka workshops and courses in many Ukrainian Canadian institutions.

Ukrainian Canadian cultural leaders consciously studied the phenomenon of the pysanka in its old context via early ethnographic sources that reached Canada from Ukraine. Some also conducted extensive research on pysanky as practiced by the first Ukrainian settlers on the Canadian prairies. These individuals studied old rituals connected with this phenomenon, they charted the diversity of designs from various ethnographic territories of Ukraine, and they devoted special attention to the symbolism of specific motifs (as hypothetically interpreted by some scholars mentioned above). The example of Natalia Talanchuk illustrates the teaching experiences of a great majority of the pysanka writers interviewed. She has been an activist with a number of Ukrainian organizations "since the minute [she] came to Canada" in 1947 and an active pysanka maker since the 1950s:

I have been transmitting my knowledge on the pysanka...For example, at the Ukrainian Youth Association (17) I organized different courses...It was in the 1960s, 1970s, 1980s... and at hospitals as well, because here the Ukrainian Canadian Congress (18) was helping older people who were in the hospitals, confined to their armchairs...I usually had twenty five or more people who would participate in that...

I have taught pysanka making] at schools when I was invited...For example, a few years ago Olia $\mathrm{M}$. invited me to a public school...It was a very big classroom full of children, small and big, and mothers...so, it was necessary to tell them everything, to show and to transmit it to them. It was necessary...to show them the literature, to show them the exhibits of pysanky of different kinds with different symbols, to tell them about that...

Also, I demonstrated [making pysanky] at Heritage Days...when all the nations of Edmonton which exist here (Muslims, Christians, black and white) have their tents, their exhibits, their culture, as well as Ukrainians who have their tent...And they advertise Ukrainians, so that people know what we have, what a spiritual treasure we have...

Interestingly, Natalia Talanchuk herself (as well as many other active builders of the National/Ethnic paradigm) "did not hear about the pysanka until [she] arrived in Canada." She was born in the city of Dnipropetrovs'k (eastern Ukraine), an urban area where this tradition was not practiced. She arrived in Canada as an adult political refugee after World War II in 1949. Natalia Talanchuk acquired her rich knowledge of pysanka writing and the symbolic meaning of different motifs formally, mostly through published sources from her large private collection. 


\section{Form and Design}

In contrast to the Old Country Easter egg, the National/Ethnic pysanka became consciously perceived and practiced as an art form. Moreover, it is considered "folk" (art) by the participants in the tradition, and this term increases its value, awakening pride in Ukrainian cultural heritage. National/Ethnic pysanka designs are applied to other forms such as, for example, ostrich eggs that could not have been part of the Old Country paradigm. National/Ethnic Easter eggs are often creatively framed for the purposes of decorative artistic display (figures 3 and 4). As an art form, the pysanka has attracted male creators as well.

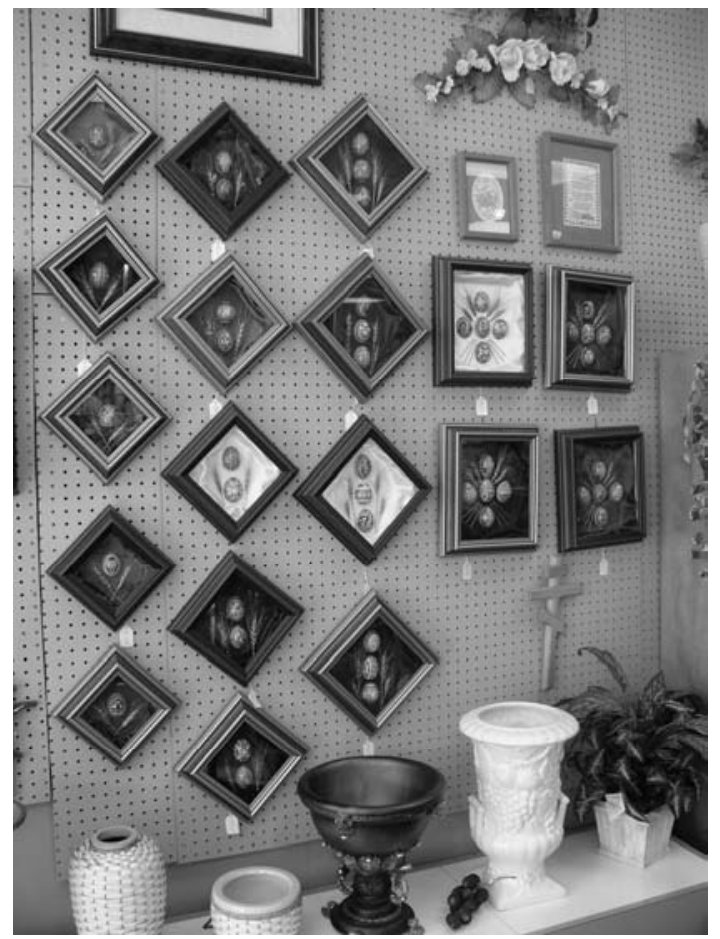

Figure 3. National/Ethnic "framed pysanky" of different compositional structures displayed at the Floral Boutique in Vegreville, Alberta. 2005. 


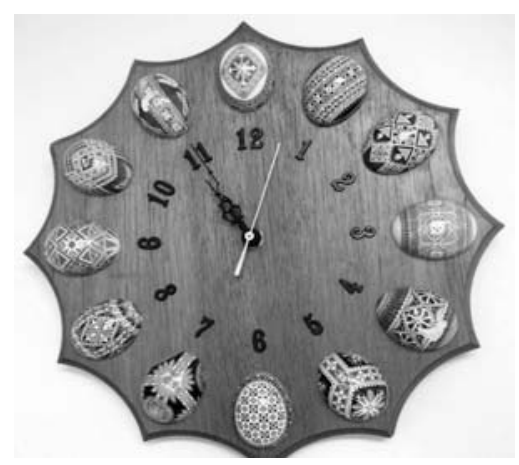

Figure 4. "Pysanka wall clock" of the National/Ethnic paradigm: Nahachewsky's wedding gift, 1983.

As a result of the rapid spread of published materials, a great number of motifs, originally connected with different ethnographic regions in Ukraine, were disseminated to form a large composite repertoire. Often, different regional designs could be incorporated into one person's work. A somewhat unique example of this is the titanic pysanka project of Myroslav (Chester) Kuc, a well-known pysanka maker from Edmonton. During the last few years, he has reproduced over two and a half thousand Easter eggs from all regions of Ukraine, on the basis of the photographs from the collection in the L'viv Museum of Ethnography in Ukraine and other sources (figure 5). One of Kuc's goals was to make the public aware of the richness of Ukrainian heritage as represented in diverse pysanka designs from various parts of Ukraine.

In addition, Trypillian designs have been adapted for Ukrainian Canadian pysanky (figure 6). (19) The discovery of the Neolithic Trypillian culture (3000-2000 BCE) on the territory of present-day Ukraine aroused great interest in Ukrainian Canadians. A variety of animal and geometric motifs found on Trypillian pottery were applied to pysanky in Canada as a source of pleasing designs and as a mark of pride in the great artistic achievements of Ukraine's predecessors. Natalia Talanchuk illustrates the perception of this phenomenon by many followers of the National/Ethnic paradigm:

They [the Trypillian designs] do not belong to the tradition [of the pysanka], but they have deep roots in our history... Thousands of years ago, people painted these symbols on their pottery, so they have lasted for millennia. That is why they are not foreign, they are traditional... 
Furthermore, creative Ukrainian Canadians have invented new motifs and produced compositions of their own. Some of these pysanky are defined as "suchasni" or "moderni," signifying "modern" on the emic level. To create such a pysanka, different geometric, floral, animal (including Trypillian) motifs tend to be stylized into minute and intricate forms and incorporated into extremely complex compositional structures (figure 6). Their intricacy is reinforced by an unlimited number of possible colour combinations, now made possible by commercial synthetic dyes.

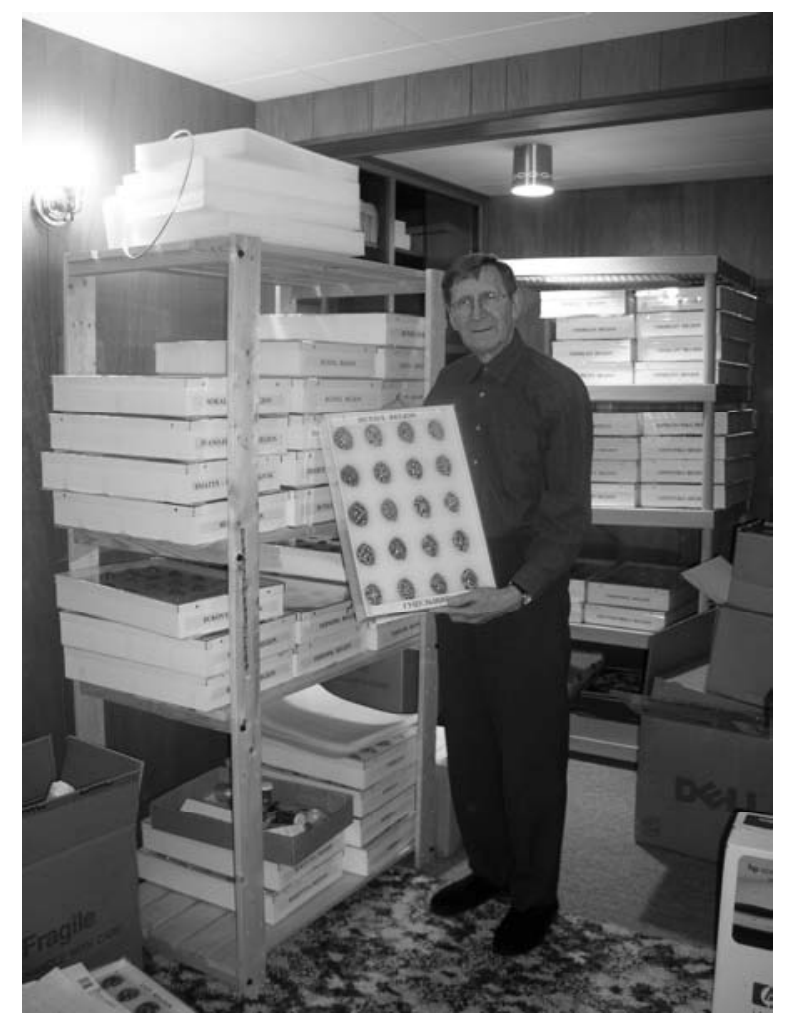

Figure 5. Pysanky of the National/Ethnic paradigm. Chester Kuc and his collection of pysanky at his home in Edmonton, Alberta. Each box contains Easter eggs representing the designs characteristic for a specific region in Ukraine. 


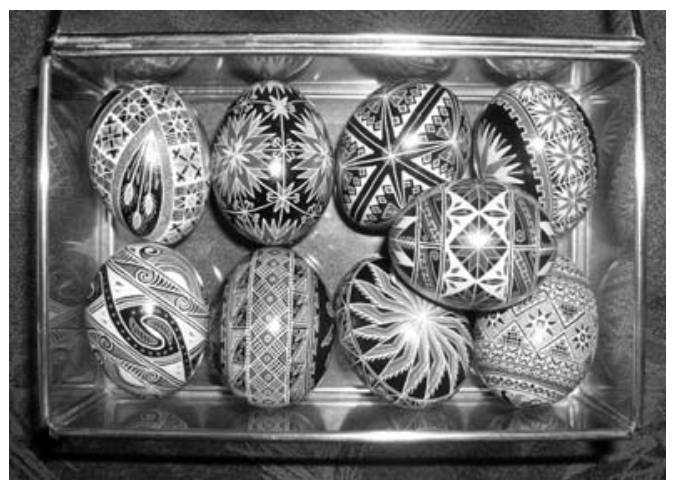

Figure 6. Box of National/Ethnic pysanky: M. Baziuk's wedding gift, 1985. Edmonton, Alberta. A "Trypillian" pysanka is in the bottom left corner.

Looking at these items, one can easily understand the current emic perspective on the Old Country Easter eggs. Most respondents, remembering pysanky writing in their families in the first part of the 20th century, now consider these "simple," "rough," "not that elaborate," as opposed to the "intricate," "fancy," and "highly elaborate" eggs that appeared in Canada "later on." (20)

However, there are always individuals who cannot be called accomplished pysanka writers. Although they formally acquired knowledge about the pysanka within this paradigm, these people write Easter eggs for the same purposes as in the Old Country - once a year prior to the Easter celebration. As a result, these pysanky tend to be simpler in design and less technically accomplished than those made by more experienced writers.

\section{Production}

National/Ethnic pysanky are predominantly made with the waxresist technique as before. However, in the National/Ethnic paradigm, the process of making pysanky has changed markedly. The rapid development of technology facilitated the introduction of advanced equipment. For example, the originally home-made stylus has been replaced by the machine-produced one, easily available at many Ukrainian stores in North America. Moreover, styluses are produced in different sizes to create lines of varying thickness. In addition, invention of an electric stylus has allowed the production of very delicate lines. A new type of pysanka equipment, called the "Craft Lathe," holds an egg and lets it be rotated, to help draw straighter lines. Commercial synthetic 
dyes have completely replaced those based on natural sources and crepe paper. Today, one can buy a kit at any Ukrainian Canadian gift store including all the necessary equipment: wax, styluses, dyes, and different patterns for pysanky.

Within the National/Ethnic paradigm, pysanky continue to be made mostly on raw eggs. Boiled eggs often are considered inappropriate, which resonates with the ideas expressed in some early ethnographic publications, i.e. the life potential of the raw egg. According to Vadym Shcherbakivs'kyi:

The pysanka was not boiled in order not to ruin in it a potential life, lifegiving power, in which lies the meaning of the pysanka...when it happened [that pysanky were boiled], it was, apparently, a result of the decline of the tradition" [Shcherbakivs'kyi 1925: 7].

In addition, boiled eggs are not used within the National/Ethnic paradigm due to new aesthetic priorities, as pointed out by Lesia Pohoreski:

I don't make mine on boiled eggs... There is a lot of hours spent in writing it as opposed to making a krashanka which is done in a minute.

In the National/Ethnic paradigm, pysanky are frequently varnished. This makes the eggshell physically stronger and reduces fading. Also, varnishing adds a special gloss to the surface of the decorated egg. In contrast to the Old Country pysanka, the contents of the eggs are often blown out, facilitating more dependable long-term preservation. Many individuals use an ordinary syringe for this, but special devices of various shapes have been developed and introduced to the community. However, as one pysanka writer says:

I blow out the eggs after I varnish them... but if I have eggs that were not blown out...before they were blessed, I have mixed feelings on this... I have a hard time blowing them out after church because that entire egg was blessed. So, how can I blow out the insides which were blessed?

This interviewee's concerns recall the early ethnographic sources focusing on the life-giving power of the raw egg and the spiritual value of an egg blessed in church. Interestingly, adherents of the National/Ethnic paradigm commonly accept blowing out eggs. Some early Ukrainian ethnographers would probably consider that a blown egg had lost its life-creating potential and spiritual power. (On the other 
hand, most raw farm eggs and especially commercially bought ones are infertile in any case).

\section{Function}

Having abandoned many of the Old Country magical rituals connected with pysanky, followers of the National/Ethnic paradigm use these objects in new contexts, related to new social, political, cultural and economic conditions. Although National/Ethnic pysanky continue to be incorporated into the Easter celebration (they are blessed in church and exchanged as gifts), adherents of this paradigm have extended the artistic tradition far beyond this religious celebration, often creating pysanky throughout the year. Pysanky now function as gifts for any occasion. Marianne Baziuk gives an example:

Kateryna [my daughter] graduated last year from a high school, and a lot of her gifts for her high school teachers were pysanky that she made last year.

So, that was a gift of love, and thanks and appreciation to the teachers.

Marianne Baziuk herself received a box of spectacular pysanky ("modern" and "Trypillian") as a wedding gift (in 1985) from her aunt (figure 6).

In contrast to eggs of the Old Country paradigm, National/Ethnic pysanky tend to be preserved for a long time. Often, this is connected with sentimental value (e.g., pysanky made by mothers or grandmothers who have since passed away or by one's children when they were little). In addition to sentimental factors, pysanky displayed in a variety of ways in the home interior serve as artistic decorations pleasing to the eye and a statement of ethnicity. National/Ethnic pysanky have also been displayed for much broader audiences, representing Ukrainian heritage in the multicultural context in Canada. Exhibitions can be of a temporary character or permanent museum displays. (21)

Since the late $1920 \mathrm{~s}$, when the pysanka began to be incorporated into a variety of structured activities, it was also connected with economic factors. If Old Country pysanky could be sold in some cases on the private level, National/Ethnic pysanky were actively incorporated into fund-raisers of different kinds and sold to a variety of buyers.(22) Some examples include collecting money for the needs of World War II, for the "pysanka for those in need in Europe" (this appeal is based on the ritual of giving pysanky away as a gift), and for the needs of different institutions, such as churches and organizations in Canada. (23) Often, pysanka fund-raisers combine both economic profit and pleasant 
diversion. Such an approach is particularly applicable to the so-called "pysanka bingo," a popular form of pysanka fund-raiser in eastern and central Canada (figure 7). (24) Playing this game, participants win pysanky instead of money.

\section{Meaning}

Within the National/Ethnic pattern, the pysanka continued to be tightly incorporated into the social and recreational life of Ukrainian families and communities. The specific events changed however. Organizing pysanka parties, exchanging pysanky as gifts after church service on Easter or playing pysanka bingo apparently reinforced the sense of community and tightened the relationship among specific individuals within the community.

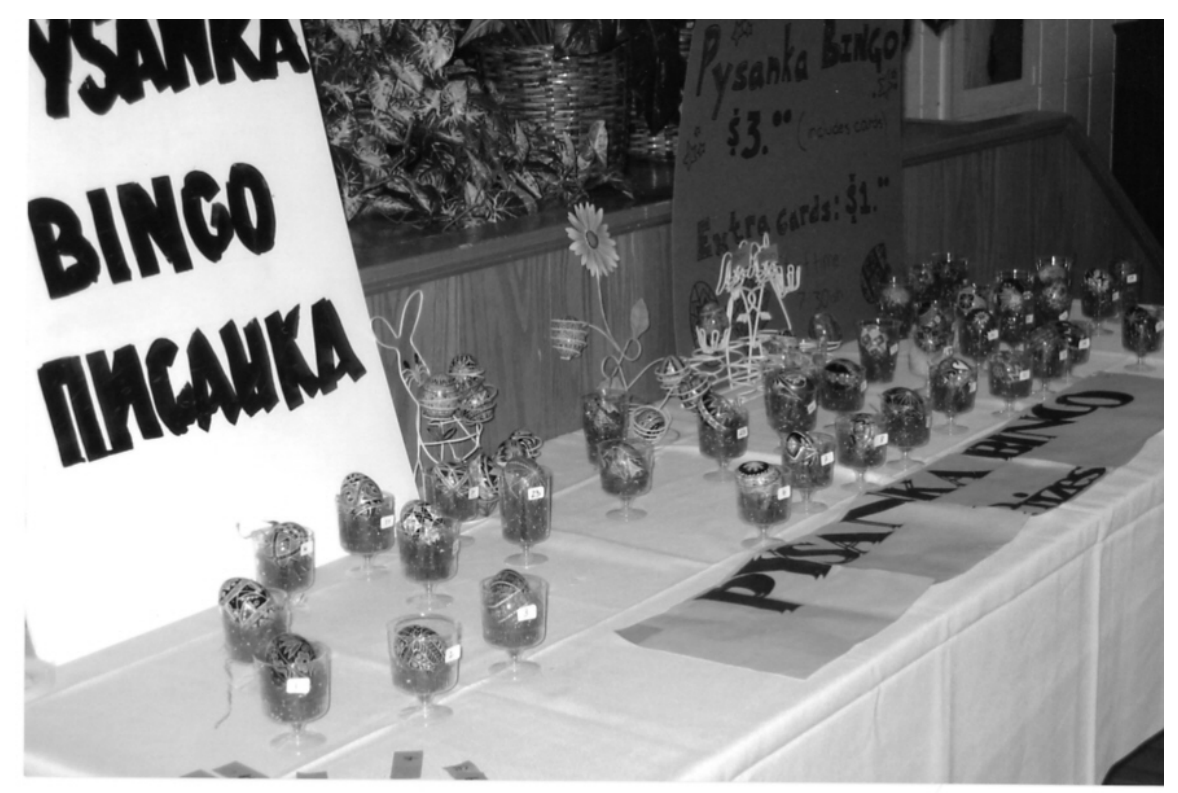

Figure 7. Pysanka Bingo at St. John's Ukrainian Orthodox Church's Auditorium in Edmonton, Alberta, c. 2003. (Photograph courtesy L. Pohoreski).

The magical beliefs connected with Old Country pysanky were mostly lost in the context of modernization. In most cases, the purposes of pysanky in the National/Ethnic paradigm differ markedly from those of the Old Country tradition. The National/Ethnic pysanka has become 
part of Ukrainian Canadian life, signifying "Ukrainianness" in the multicultural Canadian environment.

Pysanka designs have become not only aesthetically but also ideologically attractive. The focus on the "pre-historic" or "ancient" origin and "rich symbolism" of the pysanka and its motifs is a recurrent theme of popular publications. Such works often introduce the pysanka with reference to earlier ethnographic scholarship, as in the following passage:

Our scholars have researched this, our ancient culture, and they explain the meaning of the pysanka and its ornaments to us. They prove that writing pysanky reaches back to a pre-Christian era, when the cult of the sun existed in many lands as well as in Ukraine, as the provider of life on earth, exactly the thing those ancient signs-ornaments manifest on pysanky. [Iuzyk 1975: 4]

Although the author indicates no sources in her article, there is an obvious influence of earlier ethnographic sources, interpreting the pysanka as a remnant of ancient sun cults as hypothesized by such ethnographers as Sumtsov and Shcherbakivs'kyi.

Pysanka publications in the National/Ethnic paradigm present an opportunity for further popularization and interpretations of the Easter egg and its motifs in Canada. For example, Maria Iuzyk [1975: 5] writes that the "pine-tree" in combination with "sun wheels" means the "awakening of nature" (this is exactly how this motif was interpreted by Sumtsov [367]. From the same work, one can also learn that a "triangle" means trinity: fire flame, water and air; sun, thunder and fire; or husband, wife and child. In this case we can trace the influence of S. Kylymnyk's hypothesis. Kylymnyk, pointing out the tendency for personal interpretation of motifs among researchers, had previously discussed the motif "trynih" [tripod] (which is different in shape from a triangle) as follows:

...the "tripod"... has been known from the time of the Trypillian culture, it likely signifies heaven, earth and air, according to some [researchers]; according to others it means air, flame and water; still others consider it a symbol of man's life: birth, life and death; still others - heaven, earth and hell and so on. Of course, to confirm what it means exactly is difficult, especially in our times, in a foreign country. [Kylymnyk 193]

The quote below clearly exemplifies a tendency to politicize the pysanka in the author's interpretation of its motifs. In this particular case the phenomenon is meant to show the uniqueness of the Ukrainian nation to its potential enemy - the Soviet regime: 
These symbols, signs on pysanky have been used in all the territories of Ukraine, despite the borders that would be imposed [externally]...This is the evidence of our unity and our national identity, discrete from other nations a fact which is denied by our enemies. This means that they [pysanka motifs] were created at the time when we were one indivisible [independent] people. [Koshetz 4]

Such an interpretation has been influenced by ethnographic publications and the spiritual need for symbols that are meaningful in a profound way. (25) Although most contemporary Ukrainian Canadians no longer associate them with any magical power, they do believe that pysanky reflect such past magical beliefs. This conviction evokes creative imagination. Often, consulting published sources, creative individuals embed their own meaning into a pysanka, as Lesia Pohoreski shows:

When... I became a godmother, and it was my godson's first Easter, I wrote him a pysanka... I put some animals on it...I was looking at strength, I was looking at health and luck... Then I inscribed on it "Pershyi Velykden" [First Easter] and a year because I wanted to give him...a memento from khresna [godmother]... for that specific year.

\section{A similar example follows:}

I say... to my grandson: "I am giving you a pysanka with a symbol of an animal, there is a stag here; this is a symbol of happiness and health and wealth." I say to my granddaughter: "I am giving you this pysanka with cherries; cherries are a symbol of girl's beauty... I wish you to be not only beautiful, but also wise and happy" and so on. So, I would give something symbolic which can be read on the surface of the egg to everybody [in her family]..." [Talanchuk, interview]

There is no evidence that such individualized and literal applications of the motifs (symbols) were practiced in villages of Ukraine in the 19th century.

In terms of meaning, there is a noticeable change in the perception of pysanky by Ukrainian Canadians themselves. In contrast to the Old Country paradigm, in which pysanky were part of a customary lifestyle and/or old peasant worldview, in the National/Ethnic paradigm they have become consciously accepted as a continuation and preservation of tradition on the emic level. 


\section{The National/Ethnic Paradigm: Etic Interpretations}

In contrast to the Old Country pysanka, the National/Ethnic one is connected with a "formally learned" rather than "informally inherited" culture. In the multiethnic Canadian context, the pysanka has become an "external symbol" of Ukrainian national/ethnic identity, defined by Wsevolod Isajiw as: (26)

...a socio-psychological process through which individuals subjectively include themselves in a community of alleged ancestors or predecessors who share a distinct culture. What makes the process specifically ethnic is: 1) relationship to an ancestral past and 2) relationship to a distinct culture. [Isajiw 119]

National/ethnic identity is consciously constructed by a community. Builders of the National/Ethnic paradigm transferred the Easter egg from its old sacred context into a new secular one, and expanded it far beyond its original purposes, consciously "includ[ing] themselves in a community of... ancestors or predecessors," manifesting their "relationship to an ancestral past" by "sharing a distinct culture." The pysanka became what Richard Alba would call one of the "cultural elements seen as a positive heritage worth holding onto" [Alba 76].

As mentioned earlier, on the emic level, activities connected with the pysanka are undertaken in the name of "maintaining the tradition." Moreover, from the first days of their existence, many followers of the National/Ethnic paradigm struggled for 'purity' and 'truthfulness' in the pysanka-writing tradition, and against any foreign influences. "Let's cherish the purity of Ukrainian folk art...we have wonderful samples of our predecessors from Ukraine" [Zel's'ka 16], "let's not change the perfect masterpieces of our people," "we have the great richness of pysanka designs reflected in symbols" [Onyshchuk 20].(27) However, from a comparative perspective we can trace some ideological contradiction in these appeals since we see such innovations in pysanka writing as, for example, reliance on published sources, courses, and "pysanka bingo" as new contexts far from original practices.

I argue that the builders and followers of the National/Ethnic paradigm re-created the Old Country tradition, or, in other words, they created and established a tradition of their own, characterized by its own beauty, values, and spiritual power. Eric Hobsbawm and other scholars define such a cultural phenomenon as "invented tradition" which:

...is taken to mean a set of practices, normally governed by overtly or tacitly accepted rules and of a ritual or symbolic nature, which seek to inculcate

FOLKLORICA 2007, Vol. XII 
certain values and norms or behaviour by repetition, which automatically implies continuity with the past... Inventing traditions...is essentially a process of formalization and ritualization, characterized by reference to the past. [Hobsbawm 1,4]

Hobsbawm also argues that traditions are invented "not because old ways are no longer available or viable, but because they are deliberately not used or adapted" [Hobsbawm 8]. Thus, the phenomenon of "invented tradition" is not to be confused with "the strength and adaptability of genuine traditions... Where the old ways are alive, traditions need be neither revived nor invented" [Hobsbawm 8]. These ideas are relevant to the process of creating the pysanka tradition in Canada in the National/Ethnic paradigm. The large Ukrainian Canadian women's organizations (the first builders of this paradigm in pysanka decoration) were established and run mostly by nationalistically-oriented representatives of the intelligentsia, as well as descendants of Ukrainian pioneers brought up and educated in Canada. As Frances Swyripa points out, women's organizations "rejected 'peasantness' as a way of life," but promoted "Ukrainianness," "drawing on the peasants' folk art" and further politicizing it [Swyripa 1993: 158]. For them "peasantness" was no longer a way of life.(28) These individuals transferred the pysanka from its original rural peasant context into a new urban sphere which better represented their class and social status. These needs "provided the catalysts that accelerated the crucial transition from old to new, rural to urban, and folk to national" [Klymasz 1972: 8]. The new social, political and economic conditions influenced the invention of a new pysanka tradition, in which, as Hobsbawm emphasizes, "adaptation took place for old uses in new conditions and by using old models for new purposes" [Hobsbawm 5].

The "Ethnic" pole of the National/Ethnic paradigm followed the same pattern of development and shares most of its conceptual characteristics with the "National" one. The parts differ significantly in their politics. Younger generations of Ukrainian-Canadians tended to have a less strongly nationalistic outlook, and these individuals concentrated more on cultural heritage. On the basis of interviews conducted, I agree with Frances Swyripa that "old-country politics failed to hold the Canadian born" and "a cultural ethnic consciousness and not a politicized national consciousness best defines contemporary Ukrainian-Canadian identity [of the younger generation]" [Swyripa 1991: 24, 26]. In contrast to their nationalistically-directed ancestors, these people consider Canada their true home, while Ukraine is often a 
romantic place from their grandparents' stories, rich in the wisdom of their ancestors and colorful folk heritage. While many representatives of this sub-paradigm also became accomplished pysanka writers, many still practice this tradition only at Easter-time. Through the pysanka, followers and representatives of the Ethnic pole of the paradigm also manifest their "Ukrainianness" and pride of belonging to a distinctive culture and simultaneously contribute a great deal to building Ukrainian ethnic identity in Canada.

\section{The Ukrainian Canadian Pysanka in the Context of Western Aesthetics}

Since one of the most significant changes in pysanka writing in Canada is its aesthetization, it is important to discuss this phenomenon in detail. Focusing on the notion of aesthetics as related to Ukrainian Canadian pysanky, I approach the category of aesthetics from Richard Anderson's perspective since his definition of Western aesthetics is broader than many other scholarly interpretations [Anderson]. On the basis of his thorough survey of the literature devoted to this notion, Anderson traces four main theories in Western aesthetics: Mimetic, Instrumental, Emotionalist, and Formalist, to one or another of which artistic activities in Western culture tend to aspire:

Mimetic theories focus on the relationship between the work of art and some material object in the sensible world that the work of art "imitates" either literally or else by capturing it in an idealized form.

Instrumental [or pragmatic] theories emphasize the functional capacity of art, requiring art to make some sort of positive contribution to the well-being of individual or society.

Emotionalist theories center on neither the material nor the social but on the psychological realm of inner experience and feelings of the individual... Emphasis may be on the artist's expression of emotions, or cathartic purging of audience members' feelings, or on the creative art.

Formalist theories do not deal with material, social, or psychological issues, but rather with aesthetic or technical challenges of the art work itself. Under the paradigm of formalism, art is thought to be a unique manifestation of "significant form," a manipulation of an artistic medium that is capable of producing a unique and arresting response in the aesthetically attuned audience member. [Anderson 234]

Whereas the pysanka of the Old Country paradigm is clearly well laden with social and spiritual significance, its connection with the narrower western definition of aesthetics is weaker. Although they often are called "folk art" from an etic perspective, Old Country Easter eggs were not really considered "works of art" by their writers. From the 
pysanka writers' point of view, the activity was not primarily to make a beautiful object. Anderson's definition of aesthetics includes an Instrumental aesthetic perspective, in which expressive activity serves as an instrument to "pave the way to a world that is socially...[and] spiritually better" [Anderson 240]. Although this aesthetic criterion is relevant to the pysanka discussed (considering the beliefs in its magical power), Anderson's description of western aesthetic theories seems least applicable to the Old Country tradition, which evolved in a cultural context that was not entirely Western. In contrast, as soon as the pysanka was transferred in a Western cultural context, it started to reflect Western aesthetic criteria.

In Anderson's terms, the Instrumental (Pragmatic) and Formalist aesthetic criteria are dominant in the National/Ethnic pysanka, with emphasis on its "National" pole. The Easter egg came to be an artistic instrument representing "Ukrainianness," satisfying social, spiritual and political goals, and simultaneously making what Anderson calls a "positive contribution to the well-being" [Anderson 234] of people in the community. The aspect of "Ukrainianness" also became clearly associated with physical (formalist) beauty in the minds of both creators and audience. The formalistic beauty of the pysanky became a great concern within the National/Ethnic paradigm. With the help of technologically advanced equipment and materials available on the market, well-trained and accomplished pysanka writers converted this phenomenon into a spectacular artistic object, seriously and positively representing the Ukrainian nation.

Though the Formalist and Instrumental aesthetic values are most important, pysanky often secondarily awake emotional sentiment among Ukrainian Canadians, relating them to Anderson's Emotionalist aesthetic criterion. For example, Natalia Talanchuk pointed out that people would often ask her the following while buying pysanky: "Do you have any eggs with the designs of Lemkivshchyna (or Bukovyna) on them? (29) My parents came from that region." For creators of this kind of art, the Emotionalist criterion expands beyond cultural factors. All the respondents emphasized the great enjoyment and pleasure they receive on a psychological level while creating pysanky. Moreover, sometimes making pysanky has an even deeper psychological effect. Sofia PoraykoKyforuk shares her story of restarting pysanka writing as a means of healing (a break in her creativity was caused by the Depression of the 1930s). In this particular case, the Emotionalist aesthetic criterion is 
closely interrelated with the Instrumental, involved for the purpose of healing:

In 1948 I became sick with nervous strain and arthritis (caused by great worries and physical over-work [on the farm], when too many responsibilities fell on [one] pair of shoulders. These diseases of stress were just being postulated then in the research laboratory where I was then studying. Since, they have become widely recognized and accepted as being caused by too much stress and strain - O.H.) The doctor advised taking up some hobby to divert one's attention from daily troubles, problems. First choice were Easter eggs. [Porayko-Kyforuk 1969: 20, 31] (30)

The same Emotionalist and Instrumental aesthetic criteria are clearly applicable in the case of the National/Ethnic paradigm with emphasis on its "Ethnic" pole. However, the Instrumental criterion is connected mostly with bettering the social, spiritual and cultural aspects of life rather than with political issues.

The relevance of Anderson's Formalist criterion varies among different individuals. While it may be important to some accomplished pysanka writers within the Ethnic sub-paradigm, it may not be a high priority for individuals who make pysanky for social entertainment or "to maintain the tradition" once a year during the pre-Easter period. As mentioned above, pysanky of these people may be very closely related to those of the Old Country paradigm - written only once a year for ritual and religious purposes, simple and technically unspectacular.

\section{Concluding remarks}

The paradigms discussed above, for the most part, are presented in their "pure" forms. In practice, however, branching out from the same source, they are interrelated and overlap in many ways. Pysanky of contrasting paradigms may be incorporated in one person's work, form a single private or museum collection, or may share similar conceptual issues. Those individuals who "informally inherited" knowledge about writing pysanky in the context of the Old Country paradigm have often further enriched it "formally" in the context of the National/Ethnic one. The list of examples can be expanded. My discussion of the Ukrainian Canadian pysanka phenomenon in terms of two contrasting paradigms is built for heuristic purposes. This is one of many ways to illustrate that traditions change dynamically in different contexts under various influences, developing new vibrant cultural formations. 


\section{NOTES}

1 This article is based on my MA thesis "Pysanka: The Ukrainian Easter Egg in Canada," defended in 2005 at the University of Alberta. An earlier version of this paper was presented at the $29^{\text {th }}$ Annual Meeting of the Folklore Studies Association of Canada in 2005. I wish to express my sincere gratitude to my supervisor Dr. Andriy Nahachewsky for his stimulating intellectual support in my research and writing. I am also greatly indebted to Dr. Natalie Kononenko for her encouragement and help with working on this article.

2 M. Shewchuk, interview; "pysanky" is the plural of "pysanka." The noun pysanka is connected with the Ukrainian verb pysaty meaning to write. That is why many Ukrainian Canadians prefer to use the verb to write in relation to pysanky, and they call themselves pysanka writers.

3 The pysanka first started to attract the attention of ethnographers at the end of the 18th century. Some major early studies of the phenomenon are mentioned below.

4 Part of the fieldwork is related to the project "Local Culture and Diversity on the Prairies," which documents everyday life and its variations in western Canada's rural communities among people of Ukrainian, French, German and English backgrounds up to 1939. This project was spearheaded at the Ukrainian Folklore Centre at the University of Alberta, and was a collaboration with other universities across western Canada. For a detailed description and discussion of the project see $<w w w$.arts.ualberta.ca/Local_Culture/ $>$. I was part of the Ukrainian team for this project, conducting interviews and creating indexes for interviews conducted by other fieldworkers. A number of those interviews that touched upon the tradition of the pysanka prior to 1939 are used for this study. I conducted over 30 additional interviews specifically for the present study, predominantly with pysanka makers. The interviewees range in age from their teens to their late 80s. I also attended one pysanka party in Edmonton, where I had the chance to observe the process of writing pysanky as practiced by many Ukrainian families today.

5 These periodicals are Zhinochyi svit [Women's world], the monthly journal of the Orhanizatsia Ukraïnok Kanady [Ukrainian Women's Organization of Canada (UWOC)] (published since 1950); Promin [Ray] published monthly by the Soiuz Ukraïnok Kanady [Ukrainian Women's Association of Canada (UWAC)] (since 1960); and the quarterly magazine Nasha doroha [Our way], issued by the Liha 
Ukraïns'kykh Katolyts'kykh Zhinok Kanady [Ukrainian Catholic Women's League of Canada (UCWLC)] (since 1970).

6 One major source of reference is N. Kohuska [1951], who focuses specifically on the UWAC's contribution to Ukrainian material culture from 1926 to 1951.

7 In my thesis, I discuss the complex evolutionary process of the pysanka in Canada in terms of four contrasting paradigms: "Old Country," "National/Ethnic," "Popular" and "Individualistic." This theoretical approach is partly based on and greatly inspired by Robert Klymasz's ideas on the Ukrainian cultural experience in Canada presented in his introductory article to the catalogue of the exhibition "Continuity and Change: The Ukrainian Folk Heritage in Canada," held in Ottawa in 1972. He defines this experience as "composed of three distinct, yet interrelated parts," labeling them "Pioneer Folk," "National Art," and "Ethnic Pop." I was also inspired by Andriy Nahachewsky's work on Ukrainian Canadian dance. In his manuscript "Dance Across Cultures," Nahachewsky deals with different conceptual issues related to dance practices such as "vival," "revival," "national," "ethnic" dances and many others. The labeling of the four "contrasting paradigms" is inspired by the ideas presented in Nahachewsky's article "Avramenko and the Paradigm of National Culture" (2003). My discussion of the pysanka within the National/Ethnic paradigm is also inspired by Natalie Kononenko's ideas on structured rituals in Soviet and post-Soviet Ukraine (2005).

8 The political map of Ukraine has differed considerably from the map of its ethnographic regions. The contemporary political map is divided into 24 regions called oblasti [pl.]. Although very fuzzy, the ethnographic boundaries are determined by certain cultural particularities, and one ethnographic region may embrace certain parts of a few oblasti, while one oblast' may include a number of ethnographic regions. For maps of the ethnographic regions created by contemporary Ukrainian ethnographers see Bilan, Stel'mashchuk [209, 222, 255].

9 For an overview of the ideas and approaches of some major European solar mytholologists see R. Dorson [57-83].

10 For a detailed discussion of conditions in Ukraine that caused mass immigration of the Ukrainian peasantry to Canada as well as early pioneers' experiences in the New Country see O. Martynovych [1990 (1985): 7-55]. Also see Martynovych [1991: 3-55]. 
11 Detailed descriptions of how to write a Ukrainian Easter egg are provided in most popular (instructional) sources on the pysanka. For example, see J. Luciow, A. Kmit and L. Luciow [1975].

12 The krashanka (or halunka), considered a simpler version of the pysanka, was widely practiced along with pysanky in Ukraine. These were boiled eggs dyed in one color, most often red. The word krashanka is formed out of the verb krasyty meaning 'to color' in some regions. Krashanky is its plural form.

13 For a detailed discussion of the national consciousness awaking among peasants in the rural communities of Galicia see J.P. Himka [59104; 143-215].

14 Most territories of Ukraine from the late $18^{\text {th }}$ to the early $20^{\text {th }}$ centuries were colonized by the Russian and Austro-Hungarian Empires. Colonization enhanced the nationalist outlook significantly. For a detailed discussion of the history of Ukraine in this period see $\mathrm{O}$. Subtelny [201-20].

15 The Russian empire collapsed under the impact of the First World War. Eastern and central Ukraine was occupied by the Soviet regime, while western territories belonged to Poland, Romania and Czechoslovakia [Subtelny 380-452].

16 For detailed information on the activities of the UWAC connected with pysanky see Kohuska [61-88].

17 The Ukrainian Youth Association (Spilka ukraïns'koi molodi (SUM)) is an émigré youth organization, established in Germany in 1946. Its statutes presented it as a patriotic institution, whose slogan is "God and Ukraine" [Vaskovych 445-7].

18 The Ukrainian Canadian Congress (Konhres ukraïntsiv Kanady $(\mathrm{KUK}))$ is an umbrella organization of the Ukrainian community of Canada, formed in 1945 in Winnipeg [Husar-Struk 357-8].

19 The Neolithic Trypillian culture was discovered on the territory of contemporary Ukraine in the late $19^{\text {th }}$ century. One of its first researchers was archaeologist V.V. Khvoiko. Archaeological excavations unearthed a great number of clay artifacts of to this culture. Numerous publications devoted to Trypillian civilization appeared in the Soviet Union, beginning in the 1930-1940s [Zbenovych 18]. Many scholars came to consider Trypillians as the ancient ancestors of Ukraine and the oldest ethnic base of Ukrainian people. Information on the Trypillian culture also reached Ukrainian communities in Canada.

20 This is a clear example of the complexity of the emic prospective. While remembering the pysanka as practiced in their 
parents' homes in the first decades of the $20^{\text {th }}$ century, elderly Ukrainian Canadians discuss it from the perspective of their current life-long experiences with pysanky, including all the changes they have undergone since pioneer times. As a result, we cannot be certain whether these individuals perceive the Old Country Easter egg the same way it was understood in the early 20th century.

21 Reportedly, the first exhibitions that included displays of pysanky were arranged in the late 1920s and early 1930s. For example, in 1929 and 1930 the UWAC was invited to organize an exhibition of folk embroidery, weaving, wood carving, and Easter eggs by the University of Saskatchewan [Kohus'ka 61-6]. Ukrainian women's periodicals have provided many reports on different exhibitions of Ukrainian art including pysanky in the context of events all over Canada. One such report describes a display of pysanky from the private collection of Chester and Luba Kuc of Edmonton, part of an exhibition they organized in August 1986, in Edmonton [Cyncar 17-18]. Reportedly, the official opening of the first Ukrainian museum in Canada was held on December 27, 1941 in Saskatoon, following years of preparation and collecting items (including pysanky) by active members of the UWAC [Kohus'ka 71-86]. Later, branches of this museum were established in Toronto, Edmonton (1944) and Winnipeg (1950) [Kohus'ka 71-86].

22 For example, in 1933 the UWAC developed the project of selling pysanky among English audiences to collect funds for the Ukrainian Pavilion at the International Exhibition in Chicago [Kohuska 67]. The pre-Easter Pysanka bazaars have been very popular all over Canada since the early 1950s. Ukrainian Canadian women's periodicals such as Zhinochyi svit, Promin', and Nasha doroha have included reports on organizing Pysanky bazaars within different branches of the organizations all over Canada.

23 For instance, the UWOC organized a Pysanka bazaar in 1940 in Fort William to raise money for the Ukrainian Golden Cross [Protsiv 1955: 89]. Another example is connected with the activities of the UWAC. This organization collected the money "for the pysanka" for Valentyn Moroz, who was liberated from a concentration camp in Europe [Chaikovs'ka 29].

24 Frequent reports on pysanka bingo organized by branches of the UWOC have been provided in Zhinochyi svit. For example, on March 23, 1979 Anna Mykhailovs'ka organized a pysanka bingo to collect funds for a building for Zhinochyi svit in Toronto [O.M. 1979: 28]. On April 
8, 1987 a pysanka bingo game was organized by the UWOC branch in Saint Catherine's, Ontario [Domynyk 22].

25 While conducting interviews, I have not met a single pysanka writer who would question such interpretations or fail to accept them as a self-evident truth.

26 Wsevolod Isajiw, discussing the symbols of Ukrainian Canadian identity, distinguishes two types - internal (invisible), embracing such factors as beliefs, values, ideas etc., and external (visible), such as food, language and artistic articles, including pysanky (119-123).

27 Such appeals have constantly appeared in periodicals Zhinochyi Svit, Nasha Doroha and Promin, in articles devoted to the Ukrainian cultural heritage, especially the pysanka.

28 In general, the Old Country peasant way of life was gradually forced out by the transition to mechanized commercial farming by the 1930s [Martynovych 1990: 143-161].

29 Lemkivshchyna and Bukovyna are ethnographic regions in the western part of Ukraine.

30 S. Porayko-Kyforuk's memoirs have been translated from Ukrainian by her daughter Octavia Hall.

\section{BIBLIOGRAPHY}

Alba, Richard. 1990. Ethnic Identity: The Transformation of White America. New Haven: Yale University Press.

Anderson, Richard. 2004 [1990]. "Western Aesthetics: A Quartet of Traditions." In Calliope's Sisters: A Comparative Study of Philosophies of Art, pp. 231-252. New Jersey: Upper Saddle River.

Bilan, Maia and Halyna Stel'mashchuk. 2000. Ukraïns'kyi strii [Ukrainian Costume]. L'viv: Feniks.

Chaikovs'ka, L. 1979. "Sviachene - Vinnipeg [Blessed food Winnipeg]." Zhinochyi svit July-August, nos. 7-8: 29.

Cyncar, Nadia. 1986. "Vystavka narodnoho Mystetstva Myroslava $i$ Liuby Kuc" [The Exhibition of folk art of Myroslav and Liuba Kuc]. Zhinochyi svit April, no. 4: 17-18.

Domynyk, Genia. 1987. "Viddil OUK - St. Catherins, Ont. [UWOC branch in St. Catherins, Ont.]" Zhinochyi svit July-August, nos. 7-8: 22.

Dorson, Richard. 1965. "The Eclipse of Solar Mythology." In The Study of Folklore by A. Dundes. Englewood Cliffs: Prentice-Hall.

Eliade, Mircea. 1986. Symbolism, the Sacred, and the Arts. Ed. Diane Apostols-Cappadona. New York: Crossroad. 
Elyjiw, Zenon. 1994. Dvadtsiat' kip pysanok: Velykyi al'bom ukrains'kykh pysanok [Sixty score Easter eggs: A comprehensive album of Ukrainian Easter eggs]. Rochester: Myron Babiuk.

Glassie, Henry. 1968. Pattern in the Material Folk Culture of the Eastern United States. University of Pennsylvania Monographs in Folklore and Folklife, vol. 1. Philadelphia: University of Pennsylvania Press.

Glassie, Henry. 1986. "The Idea of Folk Art," Afterword to Folk Art and Art Worlds, edited by J. M. Vlach and S. J. Bronner. Ann Arbor: UMI Research Press.

Himka, John Paul. 1988. Galician Villagers and the Ukrainian National Movement in the Nineteenth Century. Edmonton: Canadian Institute of Ukrainian Studies.

Hobsbawm, Eric and Terence Ranger, eds. 2000 [1983]. The Invention of Tradition. Cambridge: Cambridge University Press.

Hurhula, Iryna. 1929. "Pysanky skhidnoi Halychyny i Bukovyny $v$ zbirtsi natsional'noho muzeiu u L'vovi [Pysanky of eastern Galicia and Bukovyna in the collection of the National museum in L'viv]" Materialy do ukraïns'koi etnolohii [Materials for Ukrainian Ethnology], vol. 21-22: 131-155.

Husar-Struk, Danylo, ed. 1993. Encyclopedia of Ukraine. Vol. 5: $\mathrm{St}-\mathrm{Z}$. Toronto: University of Toronto.

Isajiw, Wsevolod. 1984. "Symbols and Ukrainian Canadian Identity: Their Meaning and Significance.” In Visible Symbols: Cultural Expression Among Canada's Ukrainians, edited by M. Lupul, pp. 119128. Edmonton: Canadian Institute of Ukrainian Studies.

Iuzyk, Maria. 1975. "Ukraïns'ka pysanka ta iï znachennia" [The Ukrainian pysanka and its meaning] Nasha doroha April-June: 4-5.

Jones, Michael Owen. 1991. "A Folklorist's Viewpoint on Ukrainian-Canadian Art." In Art and Ethnicity: The Ukrainian Tradition in Canada, edited by R. Klymasz, pp. 47-57 Hull: Canadian Museum of Civilisation.

Klymasz, Robert. 1969. "The Ukrainian Easter Egg in Canada." Ottawa: Folklore Division of the National Museum of Man.

Klymasz, Robert. 1972. Introduction to Continuity and Change: the Ukrainian Folk Heritage in Canada, pp. 5-13. Ottawa: National Museum of Man.

Kohuska, Natalka. 1952. Chvert' stolittia na hromadskii nyvi (1926 - 1951): Istoria Soiuzu Ukraïnok Kanady [Twenty Five Years of the 
Ukrainian Women's Association of Canada (1926- 1951)]. Winnipeg: Trident Press.

Kononenko, Natalie. 2005. "Soviet Ritual/Post-Soviet Ritual: Ongoing Social Engineering." Paper read at the Canadian Institute of Ukrainian Studies Seminar, 27 January, at the University of Alberta, Edmonton.

Korduba, Myron. 1899. "Pysanky na halytskii Volyni" [Pysanky of the region of Galician Volyn']. Materialy do ukraïns'koi etnolohii [Materials for Ukrainian Ethnology] 1: 169-209.

Koshetz, Tetiana. 1958. "Istoria pysanky ta iï ornamentu [A History of the pysanka and its design]." Zhinochyi Svit April, no 4: 2-4.

Kul'zhynskii, S.K. 1899. Lubenskii Muzei E. H. Skarzhynskoi: Opisanie Kollektsii Narodnykh Pysanok [The E. H. Skarzhynskaia Museum in Lubny: The Description of the Collection of Folk Pysanky] Moscow: A.A. Levenson.

Kylymnyk, Stepan. 1962. "Pysanky." In Ukraïns'kyi rikv narodnikh zvychaiakh $v$ istorychnomu osvitlenni [Calendar Year in Ukrainian Folklore], pp.189-236. Vol. 3. Winnipeg: Trident Press.

Lett, James. 1987. The Human Enterprise. A Critical Introduction to Anthropological Theory. Boulder: Westview Press.

Luciow, Johanna, Ann Kmit and Loretta Luciow. 1991 [1975, 1976, 1984, 1987] Eggs Beautiful: How to Make Ukrainian Easter Eggs. Minneapolis: Ukrainian Gift Shop.

Martynovych, Orest. 1990 [1985]. The Ukrainian Block Settlement in East Central Alberta, 1890-1930: A History. Historic Sites Services. Occasional paper 10. Edmonton: Alberta Culture and Multiculturalism.

Martynovych, Orest. 1991. Ukrainians in Canada: the Formative Period, 1891-1924. Edmonton: Canadian Institute of Ukrainian Studies.

Nahachewsky, Andriy. 2003. "Avramenko and the Paradigm of National Culture." Journal of Ukrainian Studies 28 (Winter): 31-50.

Nahachewsky, Andriy. "Dance Across Cultures: Perspectives on Folk, Ethnic, National and Character Dance." Manuscript.

O.M. 1979. "Pysankove 'bingo' na fond prymishchennia Zhinochoho svitu." [Pysanka bingo to collect funds for a building for Zhinochyi svit] Zhinochyi svit July-August, no 7-8: 28.

Onyshchuk, Odarka. 1988. "Vidkrytyi lyst do zhinok, materei $i$ vsikh, shcho liubliat' nashe mystetstvo" [An Open Letter to Women, Mothers and Everybody Who Loves Our Art] Zhinochyi svit April, no 4: 20-21. 
Porayko-Kyforuk, Sofia. 1969. "My Beginnings in Easter Egg Enscribing." Compiled and translated by Octavia Hall. Limited edition 5. Galveston.

Porayko-Kyforuk, Sofia. Sophia Kyforuk's Easter Egg Scrapbook II: 1950s-1980s. 2005.022. Bohdan Medwidsky Ukrainian Folklore Archives, University of Alberta, Edmonton.

Protsiv, Sofia. 1955. "Ukraïns'kyi zolotyi khrest [Ukrainian Golden Cross]." In Na Sluzhbi Ridnoho Narodu: Iuvileinyi zbirnyk Orhanizatsii Ukraïnok Kanady im. Ol'hy Basarab u 25-richchia vid zaisnuvannia (1930-1955) [In Service of Our Motherland: The Ukrainian Women's Organization of Canada - $25^{\text {th }}$ Anniversary - (1930-1955)], pp. 81-101. Winnipeg: Novyi shliakh [New way].

Shcherbakivs'kyi, Vadym. 1925. Osnovni elementy ornamentatsii ukraïns'kykh pysanok ta ikhnie pokhodzhennia: Studia [Principle Elements of the Ornamentation of the Ukrainian Pysanka and Their Origins: Study]. Prague: State Publishing House.

Shukhevych, Volodymyr. 1904. "Pysanky." In Hutsul'shchyna [The Hutsul region]. Vol. 4. L'viv: NTSh: 220-231.

Subtelny, Orest. 1988. Ukraine: A History. Toronto: University of Toronto Press.

Sumtsov, Mykola. 1891. "Pysanky." Kievskaia starina: 181-209; 363-383.

Swyripa, Frances. 1991. "From Sheepskin Coat to Blue Jeans: A Brief History of Ukrainians in Canada" In Art and Ethnicity: The Ukrainian Tradition in Canada, edited by R. Klymasz, pp. 11-27. Hull: Canadian Museum of Civilisation.

Swyripa, Frances. 1993. Wedded to the Cause: Ukrainian-Canadian Women and Ethnic Identity. Toronto: University of Toronto.

Vaskovych, H. 1993. "Ukrainian Youth Association." In Encyclopaedia of Ukraine, edited by D. Husar-Struk, pp. 455-456. Vol. 5: St-Z. Toronto: University of Toronto.

Yuzyk, Paul. 1953. The Ukrainians in Manitoba: A Social History. Toronto: University of Toronto Press.

Zaiatseva, I. 1957. "Pamiataimo choho zhde vid nas ridnyi krai [Let's remember what our native land expects from us]." Zhinochyi svit October, no.10: 18.

Zbenovich, V. G. 1989. Rannii ètap tripol'skoi kul'tury na territorii Ukrainy [The Early Period of the Trypillian culture on the territory of Ukraine]. Kyïv: Naukova dumka. 
Zel's'ka, Ivanna. 1985. "Plekaimo chystotu narodnoho mystetstva [Let's cherish the purity of folk art]." Zhinochyi svit September, no 9: 16. 